\title{
Thirdhand Smoke Exposure in Mice Pancreas Microstructure
}

\section{Eva Rianti Indrasari, ${ }^{1}$ Annisa Rahmah Furqaani, ${ }^{2}$ Listya Hanum Siswanti, ${ }^{3}$ Ihsan Muhammad Nauval, ${ }^{4}$ Putra Zam Zam Rachmatullah ${ }^{4}$}

${ }^{1}$ Department of Biochemistry, Nutrition, and Biomolecular, Faculty of Medicine, Universitas Islam Bandung, Bandung, Indonesia, ${ }^{2}$ Department of Medical Biology, Faculty of Medicine, Universitas Islam Bandung, Bandung, Indonesia, ${ }^{3}$ Department of Histology, Faculty of Medicine, Universitas Islam Bandung, Bandung, Indonesia,

${ }^{4}$ Medical Undergraduate Study Program, Faculty of Medicine, Universitas Islam Bandung, Bandung, Indonesia

\begin{abstract}
Cigarette residue toxins can accumulate in the body, including the pancreas, which potentially reduces pancreas function. In addition, the active compounds in cigarettes are reporting to interfere with an elevation of reactive oxygen species, leading to disruption of pancreatic microstructures. Furthermore, pancreatic cell dysfunction is responsible for developing diabetes mellitus disease. The objective of this study was to analyze the effect of thirdhand smoke exposure on mice pancreatic microstructure image. It was an in vivo laboratory experimental study with a completely randomized design at the Medical Biology Laboratory of the Universitas Islam Bandung from November 2020-June 2021. The subjects were 20 adult male mice aged 8-10 weeks, weighing 25-30 grams, in good health condition, and randomly divided into two groups (control group and treatment group exposed to thirdhand cigarette smoke for four weeks). After the completion of the exposure period, pancreatic cells isolation was performing. The parameters observed in this study were the number and diameter islet of Langerhans. Data analysis used the independent $t$ test parametric $(\alpha=5 \%)$. The results showed that the number and diameter islet of Langerhans in the treated group were significantly lower than the control group $(\mathrm{p}<0.05)$. The average number in the control group was 9.40 \pm 3.20 , while in the treatment group was $4.90 \pm 2.74$ ( $28 \%$ smaller). The average diameter of control was $225.96 \pm 50.15 \mathrm{~mm}$, while treatment was $162 \pm 49.68 \mathrm{~mm}$ ( $50 \%$ lower). In conclusion, thirdhand smoke exposure alters the pancreas microstructure. The toxic compounds on thirdhand cigarette smoke are involving in generating an elevation of free radical levels, depletion of antioxidants, and alteration of signal transduction resulted in acceleration of apoptosis rate of the islet of Langerhans, especially pancreatic $\beta$-cells.
\end{abstract}

Keywords: Pancreas microstructure; pancreatic $\beta$-cells, thirdhand smoke

\section{Pengaruh Paparan Asap Rokok Tersier pada Gambaran Mikrostruktur Pankreas Mencit}

\begin{abstract}
Abstrak
Toksik residu rokok dapat terakumulasi pada tubuh, termasuk pankeas sehingga dapat menurunkan fungsi pankreas. Selain itu, senyawa aktif dalam rokok dilaporkan meningkatkan radikal bebas yang menyebabkan kerusakan mikrostruktur pankreas. Selanjutnya, disfungsi sel pankreas meningkatkan risiko diabetes melitus. Penelitian ini bertujuan menganalisis pengaruh asap rokok tersier terhadap gambaran mikrostruktur pankreas mencit. Penelitian ini merupakan penelitian eksperimental laboratorium in vivo dengan rancangan acak lengkap di Laboratorium Biologi Medik Universitas Islam Bandung periode November 2020-Juni 2021. Subjek penelitian adalah 20 mencit jantan dewasa berumur 8-10 minggu, bobot 25-30 gram, kondisi sehat, dan dibagi secara acak menjadi dua kelompok (kelompok kontrol dan kelompok perlakuan yang mendapat paparan asap rokok tersier selama empat minggu). Setelah periode pemberian paparan selesai, dilakukan isolasi sel pankreas. Parameter yang diamati dalam penelitian ini adalah jumlah dan diameter pulau Langerhans (islet of Langerhans). Analisis data menggunakan parametrik independent $t$ test $(\alpha=5 \%)$. Hasil penelitian menunjukkan bahwa jumlah dan diameter pulau Langerhans pada kelompok perlakuan lebih rendah dibanding dengan kelompok kontrol (p<0,05). Jumlah rerata pada kelompok kontrol adalah 9,40 $\pm 3,20$, sedangkan pada kelompok perlakuan 4,90 $\pm 2,74$ (28\% lebih rendah). Diameter rerata pada kelompok kontrol adalah 225,96 $\pm 50,19 \mathrm{~mm}$ dan kelompok perlakuan 162,89 $\pm 49,68$ $\mathrm{mm}$ (50\% lebih rendah). Simpulan, paparan asap rokok tersier dapat memengaruhi gambaran mikrostruktur pankreas. Senyawa toksik pada asap rokok tersier diduga terlibat dalam peningkatan kadar radikal bebas, penurunan kadar antioksidan, dan perubahan transduksi sinyal yang mengakibatkan peningkatan laju apoptosis pulau Langerhans, terutama sel $\beta$ pankreas.
\end{abstract}

Kata kunci: Asap rokok tersier, mikrostruktur pankreas, sel $\beta$ pankreas

Received: 4 June 2021; Revised: 17 August 2021; Accepted: 19 August 2021; Published: 31 August 2021

Correspondence: Eva Rianti Indrasari, dr., M.Kes. Department of Biochemistry, Nutrition, and Biomolecular, Faculty of Medicine, Universitas Islam Bandung. Jln. Tamansari No.22, Bandung 40116, West Java, Indonesia. E-mail: evaindrasariMD@gmail.com 


\section{Introduction}

The concerns of tobacco smoking hazards are increasing due to the magnitude of public health threats posed by the chemical cessations. Toxic, mutagenic, and carcinogenic compounds were formed because of the chemical reaction between smoke residues exhaled from active smokers with chemical compounds in the air. The residues remain in the various surfaces of objects for a long period. ${ }^{1,2}$

Admittedly, cigarette residue, tertiary cigarette smoke, or thirdhand smoke (THS) left in the environment or on the surface of objects is as dangerous as primary and secondary cigarette smoke. About 50\% of the nicotine left on the clothing or skin is dissolved by sweat and absorbed into the body through the skin. Nicotine reacts with oxygen and nitrogen in free air, producing tobacco-specific nitrosamines (TSNAs) and polycyclic aromatic hydrocarbons (PAHs). Those substances can be unstable compounds at high temperatures and mutagenic. They are also carcinogenic. These compounds can be used as markers for the presence of THS or cigarette residues. ${ }^{1-3}$

Consequently, chronic exposure to THS may lead to many cellular metabolism alterations. In human bronchial epithelial cells, DNA damage from oxidative stress provoked by THS results in alveolar thickening, uncontrolled cell growth, and tumor formation. ${ }^{3,4}$ Not only affecting lung cells, but exposure to THS in mice is also related to a disturbance in glucose and fat metabolism, increased proinflammatory cytokines, and fat deposition in the liver. ${ }^{5,6}$ Thus, the condition can contribute to disruptions of hepatic metabolism interfered with the signal transduction of pancreatic cells, leading to diabetes mellitus type 2 in mice fetuses. ${ }^{7,8}$

Although THS is known to increase the risk of many diseases, the specific effects of prolonged exposure to certain organs are still debatable. In addition, there were limited resources and researches on the mechanism of THS in causing pathological conditions in nonsmokers. Therefore, the objective of this study was to analyze the effect of THS exposure on the mice's pancreas microstructure.

\section{Methods}

This was an in vivo laboratory experimental study with a completely randomized design. The subjects were 20 adult male mice aged 8-10 weeks, weighing 25-30 grams, in healthy condition, no injuries, active, and responsive. The experimental animals were randomly divided into two groups, the control and treatment groups.

The research was conducted from November 2020 to June 2021. The locations of all stages of the study were at the Medical Biology Laboratory of the Bandung Islamic University. All the experimental animals which met inclusion criteria were adapted to the research conditions (acclimatization) for one week. During the research period, the experimental animals were caged in plastic tubs measuring $28 \times 34 \times 14 \mathrm{~cm}-$ each cage filled with five experimental animals. The treatment group received TSH exposure for four weeks.

Exposure to tertiary cigarette smoke was carried out by fumigating the experimental animal cages with cigarettes. In the process of fumigating the pen, the experimental animals were transferred to another cell and carried out in a different place from the experimental animal rearing area so that the experimental animals were not exposed to cigarette smoke directly. One cigarette was entirely burned for about one hour, and the smoke was allowed to surround the cages of the treated mice. The cell was covered with a plastic cover during fumigation. It was done every day for four weeks.

After exposure period completion, animals were sacrificed by cervical dislocation, and the pancreas was isolated. Then it was fixed with $10 \%$ formalin buffer, impregnated into the paraffin block. Furthermore, the tissue on the paraffin block that had been cut was glued to the slide and stained with Harris hematoxylineosin (HE) staining. The microscopic slides were then observed using a microscope connected to a computer equipped with Optilab Viewer and Raster Image software. The number and diameter islets of Langerhans were analyzed. At the end of the study, all experimental animals left were sacrificed, and the body parts of mice that were not used in the study were collected and buried. Data analysis was performed using an independent t test ( $\alpha=5 \%$ ).

This study has obtained ethical approval from the Health Research Ethics Committee of the Universitas Islam Bandung with approval number: 111/KEPK-Unisba/XI/2020. 


\section{Results}

The data obtained in this study were the number and diameter islet of Langerhans and are listed in Table. The data in Table shows that THS exposure altered the islet of Langerhans in the pancreas. The differences were seen from two histological parameters, the number, and diameter of each islet. The treatment group was smaller in diameter and lesser amount of cells compared with the control group. The difference of two parameters observed in the two groups showed significant results statistically $(\mathrm{p}<0.05)$. The average number of islet of Langerhans in the treatment group was almost 50\% less than in control. Likewise, the diameter islet of Langerhans in the treatment group was $28 \%$ smaller than that control. These results suggest that THS exposure afflicted the microstructure of the pancreas in experimental animals.

Figure shows a histopathological description of the microstructure of the pancreas. The images are taken from sizes that represent the average diameter of each group. There were differences in histopathological features between the two groups, where the group exposed to tertiary cigarette smoke showed lower cell density and smaller diameter than the control group.

\section{Discussion}

Cigarette smoke residue that is left in the room still contains active ingredients that can last for months after cigarette smoke is diminished. Furthermore, they generally form new compounds after reacting with the surrounding

Table Number and Diameter Islet of Langerhans Observation

\begin{tabular}{lccl}
\hline \multirow{2}{*}{ Parameters } & \multicolumn{2}{c}{ Groups } & \multirow{2}{*}{ p Value } \\
\cline { 2 - 3 } & $\begin{array}{c}\text { Control } \\
(\mathbf{n = 1 0})\end{array}$ & $\begin{array}{c}\text { Treatment } \\
(\mathbf{n = 1 0})\end{array}$ & \\
\hline Average number islet $($ mean $\pm \mathrm{SD})$ & $9.40 \pm 3.20$ & $4.90 \pm 2.74$ & 0.005 \\
Average diameter islet $(\mathrm{mm})(\mathrm{mean} \pm \mathrm{SD})$ & $225.96 \pm 50.19$ & $162.89 \pm 49.68$ & 0.015 \\
\hline
\end{tabular}

Note: *independent $t$ test, $\mathrm{p}<0.05$ significant
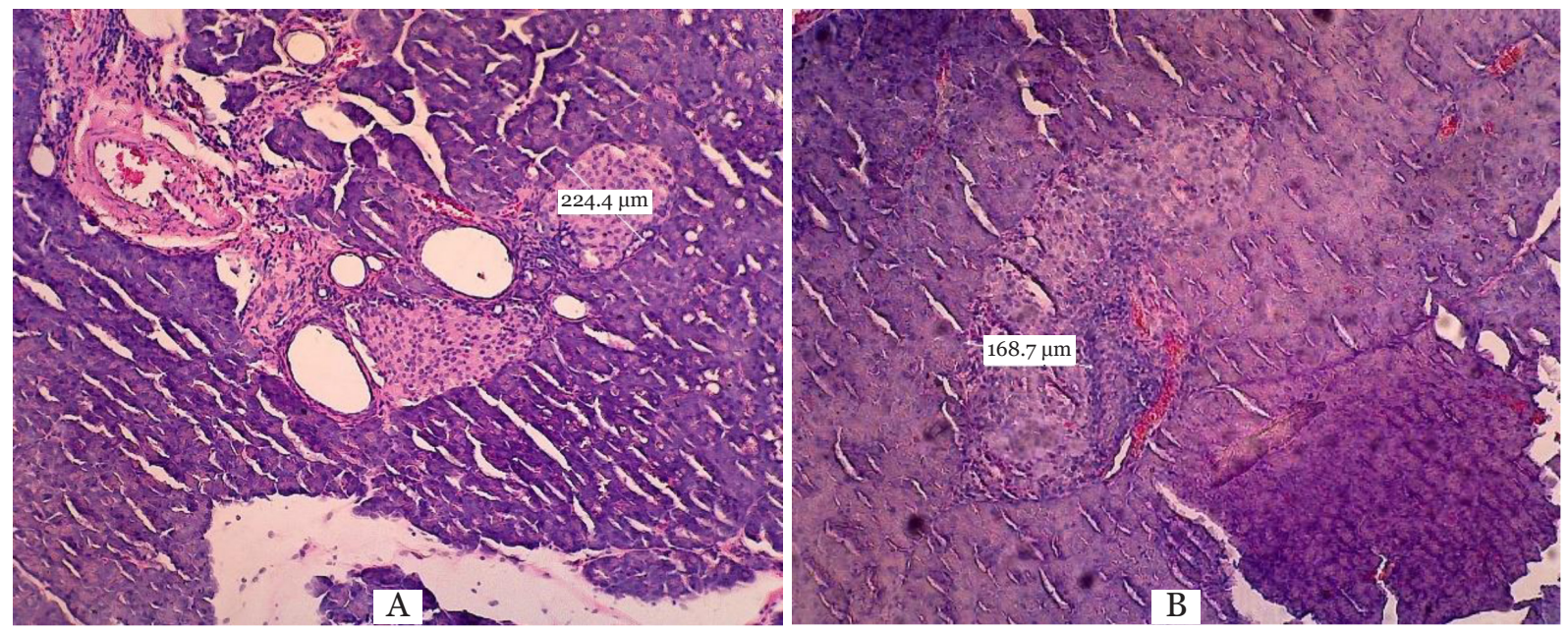

Figure Observation of the Microstructure of the Pancreas between Control and Treatment Group

(A) Histopathological microstructure of the pancreas and islets of Langerhans in the control group. The diameter appeared to be larger, and the islet of Langerhans appears to be denser than the treatment group (B).

(B) Histopathological microstructure of the pancreas and islet of Langerhans in the treatment group. The mean diameter of islet cells of Langerhans appears to be smaller, and the density of the cells is lower than the control group 
environment.

According to the results of this study, it has been shown that THS exposure in experimental animals affects pancreas microstructure. Previous studies have reported a significant association between smoking and the incidence of pancreas damage. Several theories discuss mechanisms of pancreatic damage caused by smoking, for instance, the elevation of oxidative stress and lipid oxidation induced by the active compound in cigarettes, nicotine. ${ }^{9}$ Other studies have reported that active substances in cigarettes can increase caspase-3, hypoxia-inducible factor-1 (Hif-1), Hif-2, calcitonin gene-related protein (CGRP), and TNF- $\alpha$ expression in the pancreas. Caspase- 3 is an inactive proenzyme in the cytosol, which, when activated, can induce apoptosis. Increased activation of caspase- 3 after exposure to cigarette smoke was the cause of pancreatic cell apoptosis. Exposure to cigarette smoke is also associated with increased expression of a transcription factor induced in chronic hypoxic and inflammatory conditions, hypoxia-inducible factors (Hifs). Increased Hif-1 and Hif-2 is a sign of hypoxia, and chronic inflammation has occurred in pancreatic cells exposed to cigarette smoke. ${ }^{10}$ Other proteins found to increase in pancreatic cells after exposure to cigarette smoke is CGRP-related peptide amylin. This expression of pancreatic CGRP decreases insulin release from pancreatic $\beta$-cells, causing hyperglycemia. CGRP also mediates the insulin resistance mechanism in skeletal muscles, thereby increasing the risk of diabetes mellitus. ${ }^{11}$

Adhami et al..$^{12}$ reported elevation of peripheral reactive oxygen species in mice exposed to THS and significantly decreased activity and cellular antioxidant ratio. THS toxins also disrupt the endoplasmic reticulum of pancreatic cells by causing ER stress, causing lipid, protein, and DNA damage. Consequently, the situation leads to cellular and molecular damage of pancreatic cells and insulin signaling. As a result, Mice exposed to THS had hyperglycemia, hyperinsulinemia, and a higher insulin resistance index than the control group.

Cadmium (Cd) is one of the main components of cigarette smoke. In vivo studies reported $\mathrm{Cd}$ exposure is related to the impairment of blood glucose regulation and islet of Langerhans dysfunction. Animal studies have shown that $\mathrm{Cd}$ can cause damage to pancreatic $\beta$-cells, suppress insulin secretion, increase glucose intolerance, and have a diabetogenic effect. Exposure to these compounds in the subchronic or chronic period leads to impaired glucose homeostasis, islets of Langerhans damage, lower levels of insulin secretion, and elevated gluconeogenic enzymes. ${ }^{13}$

$\mathrm{Cd}$ accumulation in blood and pancreas causing suppression of insulin secretion and apoptosis of pancreatic $\beta$-cells by inducing oxidative cellular damage in vivo and in vitro. The mitochondria of $\beta$-cells can produce excessive levels of reactive oxygen species (ROS), and they are both a major source of ROS in these cells and are also prime targets for ROS attack. Therefore pancreatic $\beta$-cells have a greater risk of developing apoptosis due to ROS attack than other cell types. When combined with the failure of the ROS defense system, these conditions can result in a relatively high susceptibility of $\beta$-cells to oxidative stress damage. ${ }^{13,14}$

Chang et al. ${ }^{14}$ reported that cadmiumassociated pancreatic $\beta$-cells damage correlates with aggravation of oxidative stress and alteration in intracellular signaling. Additionally, $\mathrm{Cd}$ exposure is also responsible for elevated malonaldehyde levels in the plasma and pancreatic cell membranes of experimental animals. Malonaldehyde is an aldehyde compound which is acts as a marker of oxidative stress in cells. Furthermore, Cd-induced altered the expression of matrix metalloproteinase (MMP) and increasing the release of cytochrome $\mathrm{c}$ from the mitochondria to the cytosol. Chang also highlighted the elevated levels of $\mathrm{Cd}$ in beta pancreas cells caused phosphorylation of c-jun N-terminal kinases (JNK). This protein mediates cell survival or apoptosis (depends on the stimuli). Accordingly, the intracellular elevation of cadmium level suspected to cause apoptosis in pancreatic $\beta$-cells.

The other main cigarette compound is nicotine. Nicotine has an essential role in enhancing premature senescence of $\beta$-cells in diabetes model mice after $12 \mathrm{~h}$ of nicotine in drinking water. Moreover, it increases intracellular $\mathrm{Ca}^{2+}$ and reactive oxygen species (ROS), which leads to further damage of $\beta$-cells after 28 days of administration. In consequence, nicotine leads to the destruction of pancreatic $\beta$-cells. ${ }^{15}$

Another study reported short-term exposure to a nicotine concentration of more than one $\mu \mathrm{mol} / \mathrm{L}$ in 48 hours inhibits insulin release. These findings indicate that pancreatic islets and $\beta$-cells had been affected in such short periods 
of exposure. Other studies have shown nicotine exposure can lead to $\beta$-cell dysfunction, increased $\beta$-cell apoptosis, and loss of $\beta$-cells chained via mitochondrial and related pathways. ${ }^{16}$

Tong et al. ${ }^{17}$ proclaimed that cigarette smoking in high-fat diet mice correlated with disruption of endoplasmic reticulum through the elevation of ceramide in $\beta$-cells compared to the non-smoking group. Admittedly, $\beta$-cells in mice with cigarette smoking treatment also exhibits deflated proliferation and had lower mass cells after 22 weeks of treatment.

The results of this study have corresponded to the effect of cigarette smoke or cigarette residues on the pancreas. The decrease in the number and diameter of islet of Langerhans is thought to be an indicator of the toxicity effect of THS exposure. Changes in the pancreas microstructure cause elevated levels of ROS, depleted of antioxidant activity, and increase the level of inflammatory cytokines and transcriptions factors such as active caspase-3, CGRP, TNF- $\alpha$, Hif- 1 , Hif-2. It also increases intracellular $\mathrm{Ca}^{2+}$. In this case, a decrease in the number and diameter of the isle of Langerhans. A reduction in number and diameter is thought to be involved in causing a decrease in pancreas ability of the pancreas to regulate or maintain blood glucose homeostasis. ${ }^{18}$ Dai et al. ${ }^{19}$ states that heavy metals contained in cigarettes include cadmium (Cd) and lead $(\mathrm{Pb})$. Cadmium has a long half-life in the human body (20-40 years); hence, it can accumulate in the body and potentially activate the oxidative stress mechanism, resulting in an elevated level of free radicals. The enhancement of free radicals is positively correlated with DNA fragmentation which triggers DNA damage.

Furthermore, the accumulation of $\mathrm{Cd}$ in pancreatic islets potentially damages cells in the islet. It alters islet function that contributes to $\mathrm{Cd}$ induced hyperglycemia. ${ }^{20}$ Another study declared that indirect exposure of nicotine to gestating mice provoked the reduction of GLUT4 expression in the muscle's offspring. Likewise, observation of pancreatic islets in this treatment group showed lower PDX-1 expression in male offspring while females had higher PDX-1, GLUT2 expressions, and lower $\alpha 2$ adrenergic receptors. These results suggested that maternal exposure to nicotine affects glycemic homeostasis and peripheral insulin signaling in offspring, thus increasing the risk for type 2 diabetes development. ${ }^{21}$ Studies have already shown that cigarette smoke causes dysfunction in pancreatic $\beta$-cells and impairs insulin production.

Nevertheless, the exact mechanisms remain unclear. Sun et al. ${ }^{22}$ demonstrated that cigarette smoke extract inhibits insulin production by upregulating thioredoxin-interacting protein via metastasis-associated lung adenocarcinoma transcript-1 (MALAT1)-mediated downregulation of microRNA (miR-17). This mechanism is involved in the reduced $\beta$-cells function. The sera of diabetic patients who smoked had higher MALAT1 levels and lowered miR-17 levels than nonsmokers' sera. Cigarette smoking increases the risk of type 2 diabetes through oxidative stress mechanisms. Oba et al. ${ }^{23}$ showed that cigarette smoking affects insulin sensitivity in Asian populations, especially the Japanese. The intensity of smoking (number and or frequency) in both active and passive smoking appears to be associated with diabetic states, including impaired glucose tolerance (IGT) and impaired fasting glucose (IFG). Even though the study showed that no significant association was observed with a homeostatic model assessment of insulin resistance (HOMA-IR) in Japanese subjects, suggesting that races may influence the glucose metabolism of smoking people. Pancreatic cancer $(\mathrm{PaCa})$ risk was also associated with smoking. The possible mechanism link might be the accumulation of advanced glycation end-products (AGEs). AGE ${ }^{\varepsilon}$-carboxymethyl lysine (CML) in human pancreatic ductal adenocarcinoma (PDA) cell lines promoted PDA cell growth and receptor for AGEs (RAGE) expression. In addition, they activated downstream tumourigenic signaling pathways. ${ }^{24,25}$ The results of this study are in line with previous research that cigarette smoke exposure may affect the structure of the pancreas and contribute to disrupting pancreatic function.

\section{Conclusions}

The results presented that thirdhand smoke exposure alters the pancreas microstructure. The toxic compounds on thirdhand cigarette smoke are involving in generating an elevation of free radical levels, depletion of antioxidants, and alteration of signal transduction resulted in acceleration of apoptosis rate of the islet of Langerhans, especially pancreatic $\beta$-cells.

\section{Conflict of Interest}

The authors have no conflict of interest to declare. 


\section{References}

1. Figueiró LR, Ziulkoski AL, Dantas DCM. Thirdhand smoke: when the danger is more than you can see or smell. Cad Saúde Pública. 2016;32(11):eooo32216.

2. Bahl V, Shima HJ, Jacob P III, Dias K, Schick SF, Talbota P. Thirdhand smoke: chemical dynamics, cytotoxicity, and genotoxicity in outdoor and indoor environments. Toxicol In Vitro. 2016;32:220-31.

3. Sleiman M, Gundel LA, Pankow JF, Jacob P III, Singera BC, Destaillats H. Formation of carcinogens indoors by surface-mediated reactions of nicotine with nitrous acid, leading to potential thirdhand smoke hazards. Proc Natl Acad Sci USA. 2010;107(15):6576-81.

4. Hang B, Sarker AH, Havel C, Saha S, Hazra TK, Schick S, et al. Thirdhand smoke causes DNA damage in human cells. Mutagenesis. 2013;28(4):381-91.

5. Benowitz NL, Burbank AD. Cardiovascular toxicity of nicotine: implications for electronic cigarette use. Trends Cardiovasc Med. 2016;26(6):515-23.

6. Morris PB, Ference BA, Jahangir E, Feldman DN, Ryan JJ, Bahrami H, et al. Cardiovascular effects of exposure to cigarette smoke and electronic cigarettes: clinical perspectives from the Prevention of Cardiovascular Disease Section Leadership Council and Early Career Councils of the American College of Cardiology. J Am Coll Cardiol. 2015;66(12):1378-91.

7. Vallaster MP, Kukreja S, Bing XY, Ngolab J, Zhao-Shea R, Gardner PD, et al. Paternal nicotine exposure alters hepatic xenobiotic metabolism in offspring. eLife. 2017;6:e24771.

8. Esakky P, Hansen DA, Drury AM, Felder P, Cusumano A, Moley KH. Paternal exposure to cigarette smoke condensate leads to reproductive sequelae and developmental abnormalities in the offspring of mice. Reprod Toxicol. 2016;65:283-94.

9. Alexandre M, Pandol SJ, Gorelick FS, Thrower EC. The emerging role of smoking in the development of pancreatitis. Pancreatology, 2011;11(5):469-74.

10. Topsakal S, Ozmen O, Aslankoc R, Aydemird DH. Pancreatic damage induced by cigarette smoke: the specific pathological effects of cigarette smoke in the rat model. Toxicol Res (Camb.). 2016;5(3):938-45.

11. Russell FA, King R, Smillie SJ, Kodji X,
Brain SD. Calcitonin gene-related peptide: physiology and pathophysiology. Physiol Rev. 2014;94(4):1099-142.

12. Adhami N, Starck SR, Flores C, Martins Green M. A health threat to bystanders living in the homes of smokers: how smoke toxins deposited on surfaces can cause insulin resistance. PLoS One. 2016;11(3):e0208056.

13. Milnerowicz H, Śliwińska-Mossoń M, Sobiech KA. The effect of ozone on the expression of metallothionein in tissues of rats chronically exposed to cadmium. Environ Toxicol Pharmacol. 2017;52:27-37.

14. Chang KC, Hsu CC, Liu SH, Su CC, Yen CC, Lee MJ, et al. Cadmium induces apoptosis in pancreatic $\beta$-cells through a mitochondriadependent pathway: the role of oxidative stress-mediated c-Jun N-terminal kinase activation. PLoS One. 2013;8(2):e54374.

15. Hermann PC, Sancho $P$, Cañamero $M$, Martinelli P, Madriles F, Michl P, et al. Nicotine promotes initiation and progression of KRAS-induced pancreatic cancer via Gata6-dependent dedifferentiation of acinar cells in mice. Gastroenterology. 2014;147(5):1119-33.e4.

16. Ario MD. Pengaruh nikotin dalam rokok pada diabetes melitus tipe 2. Majority. 2014;3(7):75-80.

17. Tong X, Chaudry Z, Lee C, Bone RN, Kanojia S, Maddatu J, et al. Cigarette smoke exposure impairs $\beta$-cell function through activation of oxidative stress and ceramide accumulation. Mol Metab. 2020;37:100975.

18. Nauval IM, Furqaani AR, Indrasari ER. Pengaruh paparan asap rokok tersier terhadap kadar glukosa darah mencit. JIKS. 2020;2(1):39-42.

19. Dai JB, Wang ZX, Qiao ZD. The hazardous effects of tobacco smoking on male fertility. Asian J Androl. 2015;17(6):954-60.

20. Fitzgerald R, Olsen A, Nguyen J, Wong W, El Muayed M, Edwards J. Pancreatic islets accumulate cadmium in a rodent model of cadmium-induced hyperglycemia. Int $\mathrm{J} \mathrm{Mol}$ Sci. 2020;22(1):360.

21. Pietrobon CB, Lisboa PC, Bertasso IM, Peixoto TC, Soares PN, de Oliveira E, et al. Pancreatic steatosis in adult rats induced by nicotine exposure during breastfeeding. Endocrine. 2021;72(1):104-15.

22. Sun Q, Xu H, Xue J, Yang Q, Chen C, Yang $\mathrm{P}$, et al. MALAT1 via microRNA-17 regulation of insulin transcription is involved in the 
dysfunction of pancreatic $\beta$-cells induced by cigarette smoke extract. J Cell Physiol. 2018;233(11):8862-73.

23. Oba S, Suzuki E, Yamamoto M, Horikawa Y, Nagata C, Takeda C, Gifu Diabetes Study Group. Active and passive exposure to tobacco smoke in relation to insulin sensitivity and pancreatic $\beta$-cell function in Japanese subjects. Diabetes Metab. 2015;41(2):160-7. 24. Zanini S, Renzi S, Limongi AR, Bellavite P,
Giovinazzo F, Bermano G. A review of lifestyle and environment risk factors for pancreatic cancer. Eur J Cancer. 2021;145:53-70.

25. Menini S, Iacobini C, de Latouliere L, Manni I, Ionta V, Blasetti Fantauzzi C, et al. The advanced glycation end-product $\mathrm{N}^{\varepsilon_{-}}$ carboxymethyllysine promotes progression of pancreatic cancer: implications for diabetes-associated risk and its prevention. $\mathrm{J}$ Pathol. 2018;245(2):197-208. 